\title{
Maps, Genealogical Tables and Illustrations
}

Map 3.I The Scottish realm c. I250 45

Map 4.I The Kingdom of the Isles and its neighbours in the thirteenth century 69

Map 9.I The Scottish Wars I 296-I328 I80

Map i i.I The Scottish Wars I332-56 233

Map I5.I Scotland I357-7I 3 3

Table I.I The Royal House of Scotland I2 I4-90 Io

Table 2.I Galloway and Carrick 38

Table 3.I The Comyns and the Disinherited 50

Table 4.I The Kingdom of the Isles 77

Table Io.I The Bruce Dynasty I306-7I 2 I 5

Table I 5.I Stewart, Douglas and Randolph 340

Figure 4.I Dunstaffnage Castle 73

Figure 5.I Bothwell Castle 104

$\begin{array}{lll}\text { Figure 5.2 Kildrummy Castle } & \text { I05 }\end{array}$

Figure 6.I Elgin Cathedral

Figure I5. I Tantallon Castle 330

Figure I5.2 Threave Castle 33 I 